\title{
Analisis Efisiensi Teknis Usaha Penggemukan Sapi Potong di Kabupaten Agam Provinsi Sumatera Barat
}

\section{Technical Efficiency Analysis of Beef Cattle Fattening in Agam District West Sumatera Province}

\author{
I. Indrayani ${ }^{1}$, R. Nurmalina ${ }^{2}$ dan A. Fariyanti $^{2}$ \\ ${ }^{1}$ Fakultas Peternakan Universitas Andalas \\ Kampus Unand Limau Manis Padang, 25163 \\ ${ }^{2}$ Departemen Agribisnis, Fakultas Ekonomi dan Manajemen Institut Pertanian Bogor \\ e-mail: ida.indrayani@gmail.com
}

(Diterima: 23 September 2011; Disetujui: 25 Januari 2012)

\begin{abstract}
The domestic beef cattle producers have supplied only 70 percent of the national need. Demand of the beef cattle has not been accompanied by an increasing of supply response. One of the major problems in beef cattle farming is its low productivity that might be caused by its low efficiency of input use. Therefore, this study aims are (1) to estimate the factors that influence the production of beef cattle fattening, (2) to analyze the level of technical efficiency of beef cattle fattening. The stochastic production frontier is used to estimate production function. The results showed that quantity of concentrate, dummy of cattle's age, and dummy of livestock ownership significantly influence production. The average value of the farm technical efficiency is 0.764 ranging from a minimum of 0.478 to a maximum of 0.996 .
\end{abstract}

Keywords: beef cattle fattening, technical efficiency, stochastic frontier

\section{PENDAHULUAN}

Daging merupakan salah satu bahan pangan yang sangat penting dalam mencukupi kebutuhan gizi masyarakat, dan merupakan komoditas ekonomi yang mempunyai nilai sangat strategis. Untuk memenuhi kebutuhan daging di Indonesia terutama berasal dari daging unggas, daging sapi, daging kerbau serta daging kambing dan domba. Konsumsi daging sapi di Indonesia setiap tahun selalu meningkat, sejalan dengan bertambahnya jumlah penduduk, peningkatan pendapatan dan kesejahteraan masyarakat serta semakin tingginya tingkat kesadaran masyarakat akan pentingnya protein hewani (Diwyanto et al., 2005).

Program Swasembada daging sapi 2014 sebagaimana yang dituangkan dalam Peraturan Menteri Pertanian Nomor : 59/ Permentan /HK.060/8/2007 merupakan salah satu program utama pemerintah dalam rangka mewujudkan ketahanan pangan asal ternak berbasis sumberdaya domestik. Target yang ingin dicapai adalah pemenuhan 90 persen dari kebutuhan daging sapi nasional. Pengembangan pengusahaan penggemukan sapi potong dapat dijadikan alternatif dalam rangka pemenuhan kebutuhan gizi masyarakat. Secara nasional, pertumbuhan produksi daging sapi tahun 2005-2008 mengalami penurunan rata-rata sebesar 0,08 persen per tahun, sedangkan pertumbuhan konsumsi daging sapi rata-rata 5,47 persen per tahun. Hal ini menyebabkan impor daging dan sapi bakalan tiap tahun selalu meningkat, yaitu tahun 2003-2007 rata-rata 41,36 persen per tahun dan 20,3 persen per tahun (Direktorat Jenderal Peternakan, 2009).

Kabupaten Agam yang merupakan salah satu sentra produksi sapi potong di Sumatera Barat memiliki potensi dalam pengembangan sapi potong. Usaha penggemukan sapi potong merupakan salah satu alternatif usaha yang banyak dipilih 
peternak. Hal ini karena disamping sistem pemeliharaan yang relatif mudah, periode pengusahaan juga relatif singkat. Saat ini sebagian besar peternak mengusahakan penggemukan sapi jenis peranakan Simental. Hal ini karena sapi jenis peranakan umumnya memiliki performa produksi yang lebih baik. Mata pencaharian utama masyarakat pada bidang pertanian yang mendukung penyediaan pakan baik berupa hijauan maupun limbah pertanian juga dapat dijadikan sebagai salah satu potensi pengembangan sapi potong.

Selain berbagai faktor pendukung di atas, berdasarkan survey awal di daerah penelitian, usaha penggemukan sapi potong di Kabupaten Agam juga menghadapi beberapa kendala yaitu (1) skala usaha ternak yang diusahakan masih kecil yaitu dengan kepemilikan 1-3 ekor, (2) ketersediaan bibit unggul terbatas, (3) terbatasnya akses teknologi, (4) pertambahan bobot badan sapi yang belum optimal, yaitu baru mencapai 400-500 g/hari, sedangkan pertambahan bobot badan sapi berpotensi di atas $800 \mathrm{~g} / \mathrm{hari}$, serta (4) manajemen pemeliharaan ternak relatif masih rendah. Selain kendala diatas peternak juga masih dihadapkan pada masalah keterbatasan modal yang dimiliki, sehingga sebagian peternak masih melakukan usaha dengan sistem bagi hasil. Keterbatasan modal juga menjadi penyebab peternak harus membeli bakalan yang berumur lebih muda, sehingga peternak harus melakukan pemeliharaan sapi dalam waktu yang relatif lebih lama hingga sapi tersebut dapat dijual. Semua permasalahan tersebut dapat menjadi hambatan bagi peternak dalam rangka peningkatan produksi usaha penggemukan sapi potong.

Tulisan ini menyajikan hasil penelitian yang secara umum bertujuan untuk menganalisis produksi dan efisiensi usaha penggemukan sapi potong. Tujuan secara spesifik ditujukan untuk (1) mengetahui faktor-faktor yang berpengaruh terhadap produksi usaha penggemukan sapi potong, (2) menganalisis apakah peternak sudah menggunakan faktor produksi secara efisien, dan (3) menganalisis faktor-faktor inefisiensi teknis dalam usaha penggemukan sapi potong.

\section{METODE}

\section{Lokasi, Waktu, Data dan Sampel Penelitian}

Penelitian ini dilakukan di Kecamatan Sungai Puar dan Kecamatan Tilatang Kamang, Kabupaten Agam. Pemilihan lokasi dilakukan secara purposive dengan pertimbangan bahwa lokasi tersebut merupakan daerah basis usaha peternakan sapi potong di Kabupaten Agam dan masih potensial untuk dikembangkan. Untuk setiap Kecamatan dipilih dua Nagari dengan populasi sapi jantan tertinggi yaitu pada Kecamatan Sungai Puar adalah Nagari Batagak dan Padang Laweh, sementara untuk Kecamatan Tilatang Kamang meliputi Nagari Gadut dan Koto Tangah. Di setiap kecamatan diambil 30 sampel secara proporsional dengan metode simple random sampling. Penetapan peternak yang dijadikan sampel mengacu pada sampling frame yang berisi nama-nama peternak penggemukan sapi potong yang ada di lokasi yang sudah ditetapkan sebagai lokasi penelitian. Penelitian dilakukan pada bulan April sampai Juni 2010.

Data yang digunakan dalam penelitian ini adalah data kerat lintang (cross section). Sumber data yang digunakan adalah data primer dan data sekunder. Data primer dikumpulkan dari tiap responden dengan bantuan kuesioner dan pengamatan langsung di lapangan Data yang diambil mengenai informasi usaha ternak sapi potong seperti penggunaan input, serta harga input dan output. Data sekunder dikumpulkan dari berbagai instansi terkait seperti Dinas Peternakan, Badan Pusat Statistik, Ditjen Peternakan, dan instansi terkait lainnya.

\section{Metode Analisis Data}

Analisis produksi usaha ternak sapi potong. Dalam fungsi produksi, faktor- 
faktor yang secara langsung mempengaruhi jumlah dan kualitas produk yang dihasilkan adalah faktor-faktor produksi yang digunakan. Dalam usaha penggemukan sapi potong, produksi didekati berdasarkan pertambahan bobot badan sapi, sedangkan faktor-faktor produksi yang diduga mempengaruhi pertambahan bobot badan sapi adalah jumlah hijauan, konsentrat, jumlah tenaga kerja, obat-obatan, dummy umur sapi bakalan dan dummy pola penguasaan ternak. Dengan demikian model persamaan penduga fungsi produksi frontier dari usaha penggemukan sapi potong dapat ditulis sebagai berikut :

$$
\begin{aligned}
\ln Y=\beta_{0}+\beta_{1} \ln X_{1}+\beta_{2} \ln X_{2}+ \\
\beta_{3} \ln X_{3}+\beta_{4} \ln X_{4}+\beta_{5} \ln X_{5}+ \\
\beta_{6} \ln X_{6}+B_{7} \ln X_{7}+v_{i}-u_{i}
\end{aligned}
$$

dimana :

$\mathrm{Y}=$ pertambahan bobot badan $(\mathrm{kg} / \mathrm{rata}-$ rata periode pemeliharaan)

$\mathrm{X}_{1}=$ jumlah hijauan $(\mathrm{kg} /$ rata-rata periode pemeliharaan)

$\mathrm{X}_{2}=$ jumlah konsentrat $(\mathrm{kg} /$ rata-rata periode pemeliharaan)

$\mathrm{X}_{3}=$ jumlah tenaga kerja (HOK/rata-rata periode pemeliharaan)

$\mathrm{X}_{4}=$ pengeluaran obat-obatan $(\mathrm{Rp} /$ periode pemeliharaan)

$\mathrm{X}_{5}=$ Dummy umur bakalan $\left(\mathrm{X}_{51}=1\right.$ jika bakalan cukup umur yaitu $\geq 1$ tahun dan $\mathrm{X}_{52}=0$ jika bakalan belum cukup umur atau $<1$ tahun)

$\mathrm{X}_{6}=$ Dummy pola penguasaan ternak $\left(\mathrm{X}_{61}=\right.$ 1 jika milik sendiri dan $\mathrm{X}_{62}=0$ jika sistem bagi hasil)

$\beta_{0}=$ intersep

$\beta_{\mathrm{i}}=$ koefisien parameter penduga, dimana $\mathrm{i}=1,2,3, \ldots \ldots .6$

$\mathrm{v}_{\mathrm{i}}-\mathrm{u}_{\mathrm{i}}=$ error term $\left(\mathrm{u}_{\mathrm{i}}=\right.$ efek inefisiensi teknis dalam model dan $\mathrm{v}_{\mathrm{i}}=$ efek faktor eksternaal yang tidak dimodelkan)

Nilai koefisien yang dipakai $\beta_{1}, \beta_{2}, \beta_{3}, \beta_{5}, \beta_{6}$, $\beta_{6}>0$ dan $\beta_{4}<0$. Nilai koefisien positif berarti dengan meningkatnya penggunaan input diharapkan akan meningkatkan produksi daging sapi.
Analisis inefisiensi teknis. Metode inefisiensi teknis yang digunakan dalam penelitian ini mengacu kepada efek inefisiensi teknis yang dikembangkan oleh Battese dan Coelli (1995) dalam Coelli (1996). Variabel $u_{i}$ yang digunakan untuk mengukur efek inefisiensi teknis, diasumsikan bebas dan distribusinya terpotong normal dengan $\mathrm{N} \quad\left(\mu_{i}, \sigma^{2}\right)$. Untuk menentukan nilai parameter distribusi $\left(\mu_{i}\right)$ efek inefisiensi teknis pada penelitian ini digunakan rumus sebagai berikut : $\mu_{i}=\delta_{0}+$ $\delta_{1} Z_{1}+\delta_{2} Z_{2}+\delta_{3} Z_{3}+\delta_{4} Z_{4}+\delta_{5} Z_{5}+w_{i t}$ dimana :

$\mu_{\mathrm{i}}=$ efek inefisiensi teknis

$\mathrm{Z}_{1}=$ umur peternak (tahun)

$Z_{2}=$ pendidikan formal peternak (tahun)

$\mathrm{Z}_{3}=$ pengalaman beternak sapi (tahun)

$\mathrm{Z}_{4}=$ jumlah ternak sapi yang dipelihara (ekor)

$\mathrm{Z}_{5}=$ Dummy Status Usaha $\left(\mathrm{Z}_{51}=1\right.$, jika usaha Utama dan $Z_{52}=0$, jika usaha sampingan)

Nilai koefisien yang diharapkan $: \delta_{1}>0$ dan $\delta_{2}, \delta_{3}, \delta_{4}<0$.

Agar konsisten maka pendugaan parameter fungsi produksi dan inefficiency frontier dilakukan secara simultan dengan program FRONTIER 4.1 (Coelli, 1996). Pengujian parameter stochastic frontier dan efek inefisiensi teknis dilakukan dengan dua tahap. Tahap pertama merupakan pendugaan parameter $\beta_{i}$ dengan menggunakan metode OLS. Tahap kedua merupakan pendugaan seluruh parameter $\beta_{0}, \beta_{i}$, varians $u_{i}$ dan $v_{i}$ dengan menggunakan metode Maximum Likelihood (MLE), pada tingkat kepercayaan a 15 persen. Hasil pengolahan program FRONTIER 4.1 menurut Aigner et al. (1977), dan Jondrow et al. (1982) dalam Coelli (1996), akan memberikan nilai perkiraan varians dalam bentuk parameterisasi sebagai berikut :

$$
\begin{aligned}
& \sigma^{2}=\sigma_{{ }_{v}}^{2}+\sigma^{2}{ }_{u} \\
& \gamma=\frac{\sigma_{u}^{2}}{\sigma^{2}{ }_{v}}
\end{aligned}
$$


Parameter dari varians ini dapat mencari nilai $\gamma$, oleh sebab itu $0 \leq \gamma \leq 1$. Nilai parameter $\gamma$ merupakan kontribusi efisiensi teknis di dalam efek residual total.

\section{HASIL DAN PEMBAHASAN}

Usaha penggemukan sapi potong di Kabupaten Agam dilakukan dengan sistem kereman, dengan rata-rata periode pemeliharaan selama 14,3 bulan. Bangsa sapi ang dipelihara adalah sapi peranakan Simental dengan rata-rata jumlah kepemilikan sapi per peternak adalah 2,4 ekor.

\section{Deskripsi Variabel Usaha Penggemukan Sapi Potong}

Statistik deskriptif berguna untuk mengetahui karakter dari sampel yang diteliti dalam penelitian. Dari statistik deskriptif tersebut dapat diketahui nilai ratarata, nilai minimum, nilai maksimum dan standar deviasi.

Rata-rata produksi (pertambahan bobot badan) sapi potong di Kabupaten Agam sebesar 298,22 $\mathrm{kg}$ dengan nilai minimum adalah $135,20 \mathrm{~kg}$ dan nilai maksimum sebesar 524,80 kg. Nilai standar deviasi pertambahan bobot badan sapi sebesar 95,87, dimana nilai tersebut lebih kecil dari nilai rata-rata menunjukkan bahwa data terkumpul dan terdistribusi normal. Sedangkan rata-rata jumlah hijauan yang diberikan peternak sebesar $28349,75 \mathrm{~kg}$ dengan standar deviasi lebih kecil yaitu sebesar 5180,79, mengindikasikan bahwa data terdistribusi normal. Hal yang sama juga ditunjukkan pada variabel Tenaga Kerja, dimana untuk variabel tersebut nilai standar deviasinya juga lebih kecil dibandingkan nilai rata-ratanya. Sedangkan untuk variabel jumlah konsentrat dan tenaga kerja nilai standar deviasinya lebih besar dari nilai rata-ratanya, yang berarti data cukup bervariasi. Namun dalam analisis produksi sudah menggunakan $\log$ atau $\ln$, sehingga data sudah dinormalisasi dan menjadi lebih baik.

\section{Analisis Faktor-faktor yang Mempengaruhi Produksi Usaha Penggemukan sapi Potong di Kabupaten Agam}

Dalam menduga fungsi produksi, semua variabel input yang diduga berpengaruh terhadap produksi usaha penggemukan sapi potong yang dilihat dari pertambahan bobot badan sapi, dimasukkan kedalam model. Variabel tersebut terdiri dari hijauan $\left(\mathrm{X}_{1}\right)$, konsentrat $\left(\mathrm{X}_{2}\right)$, tenaga kerja $\left(\mathrm{X}_{3}\right)$, obat-obatan $\left(\mathrm{X}_{4}\right)$, dummy umur bakalan $\left(\mathrm{X}_{5}\right)$, dan dummy pola penguasaan ternak $\left(\mathrm{X}_{6}\right)$.

Hasil estimasi fungsi produksi stochastic frontier disajikan pada Tabel 2. Nilai sigma squared $\left(\sigma^{2}\right)$ dan gamma $(\gamma)$ berturut-turut adalah 0,022 dan 0,999, dan nyata pada taraf 99 persen. Gamma mengindikasikan keberadaan efisiensi teknis dalam proses produksi, atau variasi hasil

Tabel 1. Statistik Deskriptif Masing-masing Variabel Usaha Penggemukan Sapi Potong di Kabupaten Agam

\begin{tabular}{|c|c|c|c|c|c|}
\hline No & Variabel & Minimum & Maximum & Mean & Standar Deviasi \\
\hline 1. & Pertambahan Bobot Badan kg) & 135,20 & 524,80 & 298,22 & 95,87 \\
\hline 2. & Jumlah Hijauan (kg) & 15015,00 & 38610,00 & 28349,75 & 5180,79 \\
\hline 3. & Jumlah Konsentrat (kg) & 00 & 7850,70 & 1578,69 & 2475,83 \\
\hline & Jumlah TK (HOK) & 42.90 & 160,90 & 93,73 & 33,70 \\
\hline 5. & Pengeluaran Obat-obatan (Rp) & ,00 & $800.000,00$ & 112333,33 & 118071,60 \\
\hline 6. & Dummy Umur Bakalan & - & - & - & - \\
\hline & Dummy Pola Penguasaan Ternak & - & - & - & \\
\hline
\end{tabular}


yang disebabkan oleh perbedaan efisensi teknis. Nilai ratio generalized likelihood (LR) dari fungsi produksi stochastic frontier adalah 14,05 dan lebih besar dari pada nilai kritis pada Tabel Kodde dan Palm (1986) yaitu 11,91, dimana signifikan pada $\alpha=5$ persen yang berarti ada efek inefisiensi teknis dalam model pada teknologi tertentu. Dalam fungsi produksi variabel-variabel yang berpengaruh nyata terhadap pertambahan bobot badan sapi adalah jumlah konsentrat, dummy umur bakalan, dan dummy pola penguasaan ternak. Sedangkan untuk Variabel jumlah hijauan, tenaga kerja dan pengeluaran obat-obatan tidak berpengaruh nyata.

Jumlah Hijauan $\left(\mathbf{X}_{\mathbf{1}}\right)$. Koefisien hijauan bertanda positif yaitu 0,119 yang berarti jika penggunaan hijauan ditingkatkan sebesar sepuluh persen, maka akan meningkatkan bobot badan sapi sebesar 1,19 persen. Pada penelitian ini koefisien hijauan tidak berpengaruh nyata terhadap pertambahan bobot badan sapi. Hal ini karena empiris di lapangangan peternak memberikan hijauan dalam jumlah yang banyak dengan frekuensi 2 kali sehari, yaitu pagi dan sore hari. Proses memamah-biak (ruminasi) pada ternak ruminansia berlangsung secara periodik, dimana proses ruminasi ini dapat terganggu apabila volume pakan yang masuk lebih besar dari kapasitas lambung. Akibatnya bolus pakan yang belum sempat dicerna akan dapat langsung masuk kedalam alat digesti selanjutnya (usus). Pemberian hijauan sebaiknya dihindari pemberian yang sekaligus dan dalam jumlah yang banyak, dimana dianjurkan pemberian dilakukan secara bertahap dan minimal 4 kali dalam sehari semalam (Siregar, 2008).

Jumlah Konsentrat $\left(\mathbf{X}_{2}\right)$. Koefisien konsentrat berpengaruh positif dan signifikan pada taraf $(\alpha=5$ persen). Koefisien konsentrat sebesar 0,006 berarti peningkatan pemberian konsentrat sebagai pakan ternak sebesar 10 persen berpeluang meningkatkan bobot badan sapi sebesar 0,06 persen. Konsentrat adalah bahan pakan yang berkonsentrasi tinggi dengan kadar serat kasar yang relatif rendah dan mudah dicerna. Fungsinya adalah meningkatkan dan memperkaya (pelengkap) nilai gizi pada bahan pakan lain (hijauan) yang nilai gizinya rendah. Konsentrat yang dimaksud dalam penelitian ini adalah campuran dari berbagai bahan pakan yang terdiri dari dedak, kulit ubi, dan mineral. Ternak sapi yang hanya diberi pakan hijauan tanpa pakan konsentrat tidak mungkin pertambahan bobot badannya maksimal. Jumlah pemberian konsentrat yang dianjurkan oleh Direktorat Jenderal Peternakan adalah 1 persen dari bobot badan. Pemberian konsentrat di daerah penelitian yaitu rata-rata 1,3 persen dari bobot badan. Hasilnya, pertambahan bobot badan sapi rata-rata di daerah penelitian adalah $0,5 \mathrm{~kg}$ per hari pada Kecamatan Sungai Puar dan $0,75 \mathrm{~kg}$ per hari di Kecamatan Tilatang Kamang.

Hasil penelitian Sidauruk et al. (2001) untuk sapi jenis Brahman Cross, setiap penambahan satu persen konsentrat menyebabkan penambahan 0,0416 persen bobot akhir sapi pada penggemukan pola fattening. Target pertumbuhan sapi potong yang dicanangkan oleh Menteri Pertanian dalam program Percepatan Pencapaian Swasembada Daging Sapi (P2SDS), pertambahan bobot badan sapi untuk sapi keturunan adalah diatas $0,9 \mathrm{~kg} / \mathrm{ekor} / \mathrm{hari}$, sedang untuk sapi PO diatas 0,7 $\mathrm{kg} / \mathrm{ekor} / \mathrm{hari}$.

Jumlah Tenaga Kerja $\left(\mathbf{X}_{3}\right)$. Koefisien tenaga kerja berpengaruh positif namun tidak nyata berpengaruh terhadap pertambahan bobot badan sapi. Koefisien tenaga kerja adalah 0,033 menunjukkan bahwa penambahan jumlah jam kerja pada penggemukan sapi potong memungkinkan pertambahan bobot badan sapi meningkat sebesar 0,33 persen. Curahan jam kerja tidak berpengaruh nyata, hal ini terkait dengan perbedaan curahan jam kerja diantara peternak lebih disebabkan oleh perbedaan waktu yang diperlukan untuk mencari hijauan, dimana bagi peternak yang menempuh jarak yang lebih jauh akan 
menghabiskan waktu lebih lama. Sedangkan dalam hal pengelolaan ternak relatif sama, seperti kebersihan kandang dan waktu pemberian pakan. Kondisi empiris di daerah penelitian, bahwa proporsi tenaga kerja yang banyak digunakan untuk pengelolaan sapi potong adalah tenaga kerja keluarga. Curahan jam kerja peternak untuk pengelolaan sapi potong adalah 1,7 jam per ekor per hari, atau 0,213 HOK per ekor per hari, dimana sebagian besar digunakan untuk mencari atau menyediakan hijauan. Jadi satu HOK mampu menangani 4 sampai 5 ekor ternak. Produksi masih dapat ditingkatkan dengan meningkatkan jam kerja dalam pengelolaan sapi potong terutama curahan waktu untuk perawatan ternak, seperti sanitasi kandang, penyiapan pakan, dan memandikan ternak. Hal ini sangat penting dalam rangka menjaga kesehatan ternak. Tidak jauh berbeda dengan hasil penelitian Mulyanuddin (1996) menyatakan satu HOK hanya mampu menangani empat ST (Satuan Ternak). Penelitian Elly (2008) menghasilkan ketersediaan tenaga kerja keluarga pada usaha ternak sapi di Bolaang Mongondow berpengaruh dalam peningkatan produksi sapi, sedangkan di Minahasa tidak mempengaruhi produksi sapi.

Pengeluaran Obat-obatan $\left(\mathbf{X}_{4}\right)$. Koefisien pengeluaran obat-obatan bertanda negatif, namun tidak nyata. Hal ini terkait dengan nilai koefisien elastisitas permintaan faktor produksi bertanda negatif, yang menjelaskan adanya hubungan negatif antar permintaan faktor produksi variabel terhadap harganya. Kenaikan harga obat-obatan menyebabkan penggunaan obat-obatan cenderung berkurang, sehingga upaya peternak terhadap pengobatan dan pencegahan penyakit ternaknya menurun. Obat- obatan yang sering diberikan berupa antibiotik dan obat cacing, sedangkan obatobatan lain biasanya berupa vitamin, namun itupun tidak diberikan secara rutin. Vitamin biasanya diberikan waktu pertama kali sapi sampai di kandang atau saat awal penggemukan dilakukan, dan selanjutnya beberapa peternak memberikannya satu kali enam bulan. Hasil penelitian Yunus (2009) pada ternak ayam ras pedaging menunjukkan bahwa variabel vaksin, obatobatan dan vitamin berpengaruh nyata dan mempunai hubungan negatif terhadap output yang dihasilkan.

Dummy Umur bakalan $\left(\mathbf{X}_{6}\right)$. Koefisien dummy umur bakalan berpengaruh positif, dan nyata pada $\alpha=1$ persen . Tanda positif mengindikasikan penggemukan sapi potong dengan sapi bakalan yang digunakan berada pada fase pertumbuhan, maka akan berpengaruh positif terhadap pertambahan bobot badan sapi. Empiris di lapangan menunjukkan bahwa 46,67 persen dari peternak menggunakan sapi bakalan dengan umur diatas satu tahun. Sugeng (2006), menyatakan bahwa penggemukan sebaiknya dilakukan pada ternak sapi usia 12-18 bulan atau paling tua umur 2,5 tahun. Pembatasan usia ini dilakukan atas dasar bahwa pada usia tersebut ternak tengah mengalami fase pertumbuhan dalam pembentukan kerangka maupun jaringan daging.

Dummy Pola Penguasaan Ternak $\left(\mathbf{X}_{7}\right)$. Koefisien dummy pola penguasaan ternak bertanda positif dan nyata berpengaruh terhadap pertambahan bobot badan sapi pada $\alpha=15$ persen. Tanda yang positif mengindikasikan bahwa penguasaan peternak terhadap ternak, yaitu milik sendiri atau bagi hasil akan mempengaruhi peternak dalam mengelola usahanya, sehingga peternak yang usahanya adalah milik sendiri akan lebih giat dan akan dengan cepat mengantisipasi resiko kegagalan yang mungkin muncul, karena peternak tidak ingin menderita kerugian dalam usahanya tersebut. Secara umum pola penguasaan ternak sapi di daerah penelitian adalah milik sendiri (53,3 persen) dan sisanya adalah sistem bagi hasil (46,7 persen).

\section{Efisiensi Teknis Usaha Penggemukan Sapi Potong}

Nilai indeks efisiensi teknis hasil analisis dikategorikan efisien jika lebih besar dari 0,8 karena daerah penelitian merupakan 
salah satu sentra produksi sapi potong di Sumatera Barat. Tabel 3 menunjukkan bahwa nilai rata-rata tingkat efisiensi teknis yang dicapai peternak penggemukan sapi potong di lokasi penelitian adalah sebesar 0,764 . Artinya, rata-rata produktivitas yang dicapai adalah sebesar 76,4 persen yang berarti produksi masih dapat ditingkatkan sebesar 23,6 persen untuk mencapai frontier yakni produktivitas maksimum yang dapat dicapai dengan sistem pengelolaan yang terbaik. Hasil tersebut mengindikasikan bahwa sebagian besar peternak di Kabupaten Agam belum efisien dalam berproduksi, karena rata-rata tingkat efisiensi yang dicapai masih di bawah 80 persen.
Tabel 3 menunjukkan bahwa secara umum tingkat efisiensi teknis usaha ternak relatif merata, dimana dari seluruh peternak yang mengusahakan penggemukan sapi potong yang diteliti, 63,33 persen berada pada $0,61-0,80$. Sedangkan yang tergolong efisien (tingkat efisiensi di atas 0,80 ) hanya 31,67 persen. Hal ini berarti proporsi peternak sapi potong yang mendekati frontier (Tingkat Efisiensi Teknis mendekati 1,0) ada sebanyak 31,67 persen. Hasil penelitian juga menunjukkan rata-rata tingkat efisiensi teknis pengusahaan penggemukan sapi potong di Tilatang Kamang lebih tinggi yaitu sebesar 0,798, sedangkan Kecamatan Sungai Puar rata-rata 0,731 .

Tabel 2. Pendugaan Fungsi Stochastic Frontier dengan Menggunakan Metode Maximum Likelihood Estimates (MLE)

\begin{tabular}{lccc}
\hline \multicolumn{1}{c}{ Variabel } & Simbol & Parameter Dugaan & t-rasio \\
\hline Intersep & $\mathrm{X}_{1}$ & 6,832 & 6,732 \\
Jumlah Hijauan (kg) & $\mathrm{X}_{2}$ & 0,119 & 1,051 \\
Jumlah Konsentrat (kg) & $\mathrm{X}_{3}$ & $0,006^{* *}$ & 2,889 \\
Jumlah Tenaga Kerja (HOK) & $\mathrm{X}_{4}$ & $-0,033$ & $0,324^{* * *}$ \\
Pengeluaran Obat-obatan (Rp) & $\mathrm{X}_{5}$ & $0,323^{* * *}$ & 0,655 \\
Dummy Umur Bakalan & $\mathrm{X}_{6}$ & $0,139^{* *}$ & 3,840 \\
Dummy Pola Penguasaan Ternak & & 29,73 & \\
Log-likelihood OLS & & 36,75 & \\
Log-likelihood MLE & & 14,05 & \\
LR & &
\end{tabular}

Keterangan : ***nyata pada $\alpha 1 \%$; **nyata pada $\alpha 5 \%$; * nyata pada $\alpha 15 \%$

Tabel 3. Sebaran Efisiensi Teknis Peternak Responden

\begin{tabular}{|c|c|c|}
\hline Sebaran Nilai Efisiensi Teknis & Jumlah & Persentase $(\%)$ \\
\hline $0,41-0,50$ & 1 & 1,67 \\
\hline $0,51-0,60$ & 2 & 3,33 \\
\hline $0,61-0,70$ & 20 & 33,33 \\
\hline $0,71-0,80$ & 18 & 30,00 \\
\hline $0,81-0,90$ & 11 & 18,33 \\
\hline $0,91-1,00$ & 8 & 13,33 \\
\hline Total & 60 & 100,00 \\
\hline Rata-rata & \multicolumn{2}{|c|}{0,764} \\
\hline Minimum & \multicolumn{2}{|c|}{0,478} \\
\hline Maksimum & \multicolumn{2}{|c|}{0,996} \\
\hline
\end{tabular}


Hasil yang diperoleh lebih rendah dari penelitian Cehyan dan Haznechi (2010) yang menghasilkan bahwa Technical Efficiency (TE) yang dicapai pada usaha penggemukan sapi potong di Turkey ratarata adalah 0,92 dengan kisaran antara 0,671. Sedangkan penelitian Rae et al. (2006) yang meneliti Total Factor Productivity (TFP) dan Technical Efficiency (TE) usaha ternak di China menghasilkan bahwa selama rentang waktu 1998-2001 rata-rata pertumbuhan TFP produksi daging sapi diatas 4,5 persen sedangkan rata-rata pencapaian efisiensi teknis adalah 75 persen.

\section{Sumber-sumber Inefisiensi Teknis Usaha Penggemukan Sapi Potong}

Faktor-faktor yang mempengaruhi tingkat efisiensi teknis peternak di wilayah penelitian diduga dengan menggunakan model efek inefisiensi dari fungsi produksi stochastic frontier. Hasil pendugaan menunjukkan bahwa faktor yang berpengaruh nyata dalam menjelaskan inefisiensi teknis didalam proses produksi usaha penggemukan sapi potong, adalah faktor umur dan dummy status usaha. Diantara faktor-faktor tersebut, hasil pendugaan sesuai dengan yang diharapkan, kecuali untuk faktor umur.

Umur (Z1). Variabel umur dimasukkan dalam model efek inefisiensi teknis dengan dugaan berpengaruh positif terhadap inefisiensi teknis usaha ternak. Hasil penelitian menunjukkan bahwa umur bertanda negatif. Hal ini mengindikasikan semakin lama umur, maka peternak cenderung lebih efisien dalam menggunakan input produksi. Hal ini terjadi karena seiring dengan peningkatan usia peternak, kemungkinan pengalaman dan keterampilan mereka juga meningkat. Sejalan dengan hasil tingkat efisiensi teknis yang dicapai masing-masing peternak yaitu terdapat 31,67 persen peternak yang berada pada selang tingkat efisiensi teknis yang tergolong tinggi yaitu antara 0,81-1,00. Sebagian besar peternak $(78,9$ persen $)$ dengan tingkat efisiensi teknis yang tinggi tersebut berada pada usia diatas usia rata-rata peternak $(\geq 43$ tahun). Berbeda dengan penelitian (Umoh, 2006) yang menemukan bahwa variabel umur berpengaruh negatif terhadap inefisiensi teknis pada usahatani dipedesaan namun tidak nyata.

Pendidikan Formal (Z2). Hasil analisis menunjukkan variabel umur bertanda negatif namun tidak nyata. Variabel ini dianggap sebagai proxy dari kemampuan manajerial peternak. Semakin lama waktu yang dihabiskan peternak untuk menempuh pendidikan diduga semakin mendorong peternak untuk meningkatkan efisiensi dalam proses produksi dan penggunaan inputinput. Variabel pendidikan tidak berpengaruh nyata, karena empiris di lapangan tingkat pendidikan peternak relatif merata, dimana sebagian besar (50 persen) peternak berada pada level pendidikan Sekolah Dasar (SD). Menurut Kebede (2001) pendidikan dapat meningkatkan kemampuan petani untuk mencari, memperoleh dan mengiterpretasikan informasi yang berguna tentang input-input produksi.

Pengalaman (Z3). Pengalaman diukur berdasarkan selang waktu peternak menjalankan usaha penggemukan sapi potong. Pada beberapa penelitian sebelumnya, pengalaman dianggap sebagai proxy dari umur petani khususnya pada sistem pertanian tradisional. Hasil penelitian diperoleh pengalaman peternak yang bertanda negatif, menunjukkan bahwa semakin lama pengalaman peternak dalam mengusahakan penggemukan sapi potong, maka peternak akan semakin efisien atau tingkat inefisiensi teknis semakin rendah. Tingkat pengalaman peternak selama itu akan memberikan bekal pengetahuan dan keterampilan dalam mengelola usaha ternaknya. Semakin lama pengalaman beternak, cenderung semakin memudahkan peternak dalam pengambilan keputusan yang berhubungan dengan teknis pemeliharaan usaha ternaknya. Hal tersebut disebabkan karena pengalaman dapat dijadikan pedoman 
dan penyesuaian terhadap permasalahan usaha ternak di masa mendatang.

Dummy status usaha ternak $\left(\mathbf{Z}_{4}\right)$. Status usaha ternak di wilayah penelitian terdiri dari usaha utama dan sampingan. Hasil analisis menunjukkan variabel dummy status usaha ternak berpengaruh nyata pada $\alpha=5$ persen dengan tanda negatif. Hal ini dapat dijelaskan bahwa peternak yang menjadikan usaha penggemukan sebagai usaha utama relatif lebih efisien dibandingkan peternak yang menjadikan usahanya hanya sebagai sampingan. Hal ini disebabkan peternak yang menjadikannya sebagai usaha utama, maka perhatiannya akan lebih fokus dan keinginan untuk peningkatan produksi akan lebih tinggi, karena usaha tersebut sebagai sumber penghasilan utama untuk mencukupi kebutuhan hidupnya.

Secara umum usaha penggemukan sapi potong di wilayah penelitian masih sebagai usaha sampingan, yaitu rata-rata 63,33 persen dari keseluruhan peternak responden. Empiris di lapangan dari keseluruhan peternak yang berada pada selang tingkat efisiensi teknis tergolong tinggi (selang 0,81-1,00), sebagian besar (68,4 persen) menjadikan usaha ternaknya sebagai usaha utama. Hasil analisis terhadap efek inefisiensi teknis disajikan pada Tabel 4.

Selanjutnya dapat dijelaskan varians $\left(\sigma^{2}\right)$ dan parameter gamma $(\gamma)$ model efek inefisiensi teknis fungsi produksi stochastic frontier. Pada Tabel dapat diketahui bahwa parameter $\gamma$ dugaan yang merupakan rasio dari varians efisiensi teknis $\left(u_{i}\right)$ terhadap varians total produksi $\left(\varepsilon_{i}\right)$ adalah 0,999 . Secara statistik nilai tersebut nyata pada $\alpha=$ 0,01 . Angka ini menunjukkan bahwa 99,9 persen dari variabel galat dalam fungsi produksi menggambarkan efisiensi teknis peternak atau 99,9 persen dari variasi hasil diantara peternak responden disebabkan oleh perbedaan efisiensi teknis.

Hasil ini menjelaskan bahwa hampir semua variasi dalam keluaran dari produksi batas dianggap sebagai akibat dari tingkat pencapaian teknis efisiensi yang berkaitan dengan manajerial dalam pengelolaan usaha penggemukan sapi potong.

Tabel 4. Pendugaan Efek Inefisiensi Teknis Fungsi Produksi Stochastic Frontier

\begin{tabular}{lcc}
\hline \multicolumn{1}{c}{ Variabel } & Nilai Dugaan & $\mathrm{t}-$ rasio \\
\hline Konstanta & 1,014 & 1,788 \\
Umur $\left(\mathrm{Z}_{1}\right)$ & $-0,139^{*}$ & $-1,166$ \\
Pendidikan $\left(\mathrm{Z}_{2}\right)$ & $-0,058$ & $-0,493$ \\
Pengalaman $\left(\mathrm{Z}_{3}\right)$ & $-0,029$ & $-0,838$ \\
Dummy Status Usaha $\left(\mathrm{Z}_{4}\right)$ & $-0,128^{* *}$ & $-2,175$ \\
\hline
\end{tabular}

Keterangan : ***nyata pada $\alpha 1 \%$; **nyata pada $\alpha 5 \%$; * nyata pada $\alpha 15 \%$

Tabel 5. Varians dan Parameter $\gamma$ (gamma) dari Model Inefisiensi Teknis Fungsi Produksi Stochastic frontier

\begin{tabular}{cccc}
\hline $\begin{array}{l}\text { Varians dan } \\
\text { Parameter } \gamma\end{array}$ & Nilai Dugaan & Standard Error & t-Rasio \\
\hline$\sigma_{\mathrm{s}}{ }^{2}=\sigma_{\mathrm{v}}{ }^{2}+\sigma_{\mathrm{u}}{ }^{2}$ & 0,022 & 0,005 & 1,540 \\
$\gamma=\sigma_{\mathrm{u}}{ }^{2} / \sigma_{\mathrm{s}}{ }^{2}$ & 0,999 & 0,270 & 3,703 \\
\hline
\end{tabular}




\section{KESIMPULAN}

Faktor-faktor yang berpengaruh terhadap pertambahan bobot badan sapi adalah jumlah konsentrat, dummy umur bakalan, dan dummy pola penguasaan ternak. Untuk mencapai produksi yang optimal, peternak perlu memperhatikan umur bakalan yang digunakan, dimana sebaiknya peternak menggunakan sapi bakalan yang berumur di atas satu tahun. Disamping itu penggunaan konsentrat juga perlu ditingkatkan dalam rangka peningkatan bobot badan sapi. Penggunaan konsentrat dalam usaha penggemukan sapi potong di Kabupaten Agam sudah sesuai dengan kebutuhan minimal sapi, dimana kebutuhan minimal sapi potong satu persen dari bobot badan sapi.

Rata-rata peternak penggemukan sapi potong di Kabupaten Agam belum efisien secara teknis dengan tingkat efisiensi teknis yang dicapai rata-rata adalah sebesar 0.764 dan relatif merata. Variabel yang berpengaruh nyata terhadap inefsiensi teknis usaha penggemukan sapi potong adalah variabel umur dan dummy status usaha ternak. Sementara variabel pendidikan dan pengalaman tidak berpengaruh nyata.

\section{DAFTAR PUSTAKA}

Aigner, D.J., C.A.K. Lovell and P. Schmidt. 1977. Formulation and Estimation of Stochastic Frontier Production Function Model. Journal of Econometrics, 6(1) : 21-37.

Battese, G.E. and T.J. Coelli. 1995. A model for Technical Efficiency Effects in a Stochastic Frontier Production Function for Panel Data. Empirical Economics, 20 : 325-332.

Cehyan, V., Hazneci, K. 2010. Economic Efficiency of Cattle-Fattening in Amasya Province, Turkey. Journal of Animal and Veterinary Advances, 9(1) : 60-69.
Coelli, T.J. 1996. A guide to FRONTIER Version 4.1 : A Computer Program for Stochastic Frontier Production and Cost Function Estimation. Centre for Efficiency and Productivity Analysis, University of New England, Armidale.

Direktorat Jenderal Peternakan. 2009. Statistik Peternakan. Direktorat Jenderal Peternakan, Jakarta.

Diwyanto, K., A. Priayanti, dan I. Inounu. 2005. Prospek dan Arah Pengembangan Komoditas Peternakan Unggas, Sapi, dan Kambing-Domba. Jurnal Wartozoa, 15(1) : 11-25.

Elly, F.H. 2008. Dampak Biaya Transaksi terhadap Perilaku Ekonomi Rumahtangga Peternak Usaha Ternak Sapi-Tanaman di Sulawesi Utara. Disertasi Doktor. Sekolah Pascasarjana, Institut Pertanian Bogor, Bogor.

Jondrow, J., C. A. K. Lovell, I. S. Materov and P. Schmidt. 1982. On Estimation of Technical Inefficiency in the Stochastic Frontier Production Function Model. Journal of econometrics. 19 (1) : 233238.

Kodde, D.A. and F.C. Palm. 1986. Wald Criteria for Jointly Testing Equality and Inequality Restrictions. Econometrica, 54(5) : 1243-1248.

Kebede, T.A. 2001. Farm Household Technical Efficiency : A Stochastic Frontier Analysis. A Study of Rice Producers in Mardi Watershed in the Western Development Region of Nepal. $\underline{\text { http }}$ ://www.ub.no/elpub/Norad/2001/NLH /Thesis 01.pdf (6 Januari 2009).

Rae, A.N., Hengyan Ma, J. Huang, and S. Rozalle. 2005. Livestock in China : Commodity-Specific Total Factor Productivity Decomposition Using New Panel Data. Agricultural Policy Discussioan Paper, No.20. Massey University, Palmerston North. http://caps.massey.ac.nz/dies/Ag policy 
Discussion paper No.20 pdf (15 Agustus,2010).

Sidauruk, R., L. Cyrilla, dan J. Atmakusuma. 2001. Analisis Efisiensi Pola Usaha Sapi Potong di Bekasi Jawa Barat (Kasus di PT. Lembu Jantan Perkasa). Jurnal Media Peternakan, 24(1) : 128-135.

Siregar, S.B. 2008. Penggemukan Sapi. Penebar Swadaya, Jakarta.

Sugeng, Y.B. 2006. Sapi Potong. Penebar Swadaya, Yakarta.
Umoh, G.S. 2006. Resource Use Efficiency in Urban Farming : An Application of Stochastic Frontier Production Function International Journal of Agriculture and Biology, 8(1) : 38-44.

Yunus, R. 2009. Analisis Efisiensi Produksi Usaha Peternakan Ayam Ras Pedaging Pola Kemitraan dan Mandiri di kota Palu Provinsi Sulawesi Tengah. Tesis Magister Sains. Program Pascasarjana, Universitas Diponegoro, Semarang. 